\title{
Evidence-based dentistry in German-language dental journals 1997-2003
}

\author{
JC Türp" ${ }^{1}$ C Röhrich ${ }^{2}$, G Antes ${ }^{3}$
}

${ }^{1}$ Department of Reconstructive Dentistry and Temporomandibular Disorders, Dental School, University of Basel, Basel, Switzerland

${ }^{2}$ Department of Prosthodontics, Dental School, University of Freiburg, Freiburg, Germany

${ }^{3}$ German Cochrane Centre, Institute of Medical Biometry and Medical Informatics, University of Freiburg, Freiburg, Germany

The purpose of this systematic literature search was to evaluate how the evidencebased approach appears in German-language dental journals. All volumes of 28 dental journals published between 1997 and 2003 were searched by hand; for 15 of these journals, an additional electronic search was made. The focus of the search was all articles, editorials or letters to the Editor dealing with topics related to evidence-based dentistry (EBD)/medicine or using its terminology. Of the 1776 journal issues that were scrutinised, 368 relevant publications were found. After a low, albeit slightly increasing, number of pertinent contributions published between 1997 and 1999, there was a sharp rise in 2000 and 2001, culminating in 2003. Our findings indicate a rising awareness of the concept of EBD in the German-language dental literature. Nonetheless, its reception within the German-speaking dental community is still modest.

Evidence-Based Dentistry (2005) 6, 86-87. doi:10.1038/sj.ebd.6400362

\section{Introduction}

Over the past few years, the concept of EBD has gained increasing acceptance among dentists worldwide. ${ }^{1,2}$ Some variation is to be expected in the degree of enthusiasm towards EBD between different countries, however. In fact, within the German dental community, a certain hesitancy and reluctance has been noted with regard to the integration and implementation of the evidencebased approach into clinical practice, ${ }^{3,4}$ despite the fact that the first textbook dedicated to the subject was published in Germany. $^{5}$

The aim of this study was, therefore, to assess how the evidence-based philosophy was reflected in Germanlanguage dental journals between 1997 and 2003.

\section{Materials and methods}

Twenty-eight widely distributed dental journals (25 German, two Swiss, one Austrian) were considered (Table 1). All volumes published between 1997 (start- ing with the first issue) and 2003 (ending with the last issue of that year) were carefully searched by hand from cover to cover. Each publication (articles, editorials, letters to the Editor) was read and contributions looked for included those that focussed on topics associated with EBD or evidence-based medicine. Papers in which EBD-related terminology was used (eg, the phrase "evidence-based") were also counted. For 15 out of the 28 journals, the manual search was complemented by an electronic search.

\section{Results}

Altogether, 1776 issues of 28 dental journals were scrutinised, from which 368 relevant articles were identified. Between 1997 and 1999, there was a low, slightly increasing, number of relevant publications, which was followed by a sharp rise in 2000 and 2001, culminating in 2003 (Figure 1). Between 1997 and 2003 the number of pertinent contributions had increased 50-fold. Fifty-three of the 368 publications were editorials
(14.4\%). Evidence-based medicine/EBDrelated terminology was used correctly in nine out of every 10 publications $(n=330)$.

Table 1. Journals reviewed.

\begin{tabular}{|c|c|c|}
\hline Journal & Country* & $\begin{array}{l}\text { Issues } \\
\text { searched } \\
(n)\end{array}$ \\
\hline BDIZ Konkret & $\mathrm{D}$ & 27 \\
\hline Das Dental-Labor & $\mathrm{D}$ & 84 \\
\hline Dental Magazin & $\mathrm{D}$ & 12 \\
\hline $\begin{array}{l}\text { Dental Praxis (until } \\
\text { autumn 2000: Phillip } \\
\text { Journal) }\end{array}$ & $\mathrm{D}$ & 42 \\
\hline $\begin{array}{l}\text { Dentale Implantologie und } \\
\text { Parodontologie }\end{array}$ & $\mathrm{D}$ & 42 \\
\hline Der Freie Zahnarzt & $\mathrm{D}$ & 77 \\
\hline $\begin{array}{l}\text { Deutscher Zahnärzte } \\
\text { Kalender }\end{array}$ & $\mathrm{D}$ & 7 \\
\hline Die Quintessenz & $\mathrm{D}$ & 84 \\
\hline Die Zahnarzt Woche & $\mathrm{D}$ & 335 \\
\hline $\begin{array}{l}\text { Deutsche Zahnärztliche } \\
\text { Zeitschrift }\end{array}$ & $\mathrm{D}$ & 84 \\
\hline Endodontie & $\mathrm{D}$ & 28 \\
\hline $\begin{array}{l}\text { GZM - Praxis und } \\
\text { Wissenschaft }\end{array}$ & $\mathrm{D}$ & 28 \\
\hline Implantologie & $\mathrm{D}$ & 28 \\
\hline Kieferorthopädie & $\mathrm{D}$ & 28 \\
\hline Laser Journal & $\mathrm{D}$ & 22 \\
\hline $\begin{array}{l}\text { Mund-, Kiefer- und } \\
\text { Gesichts-Chirurgie }\end{array}$ & $\mathrm{D}$ & 42 \\
\hline Oralprophylaxe & $\mathrm{D}$ & 28 \\
\hline Parodontologie & $\mathrm{D}$ & 28 \\
\hline Quintessenz Team-Journal & $\mathrm{D}$ & 82 \\
\hline Quintessenz Zahntechnik & $\mathrm{D}$ & 84 \\
\hline $\begin{array}{l}\text { Schweizer Monatsschrift } \\
\text { für Zahnmedizin }\end{array}$ & $\mathrm{CH}$ & 84 \\
\hline Stomatologie & $A$ & 60 \\
\hline Swiss Dent & $\mathrm{CH}$ & 70 \\
\hline $\begin{array}{l}\text { Zahnarzt und Praxis } \\
\text { international }\end{array}$ & $\mathrm{D}$ & 39 \\
\hline Zahnärztliche Mitteilungen & $\mathrm{D}$ & 168 \\
\hline Zahnarzt Wirtschaft Praxis & D & 65 \\
\hline $\begin{array}{l}\text { Zeitschrift für } \\
\text { Zahnärztliche } \\
\text { Implantologie }\end{array}$ & D & 28 \\
\hline$Z W R$ & $\mathrm{D}$ & 70 \\
\hline Total & 1776 & \\
\hline
\end{tabular}

${ }^{*} \mathrm{D}$, Germany; $\mathrm{CH}$, Switzerland; A, Austria. 


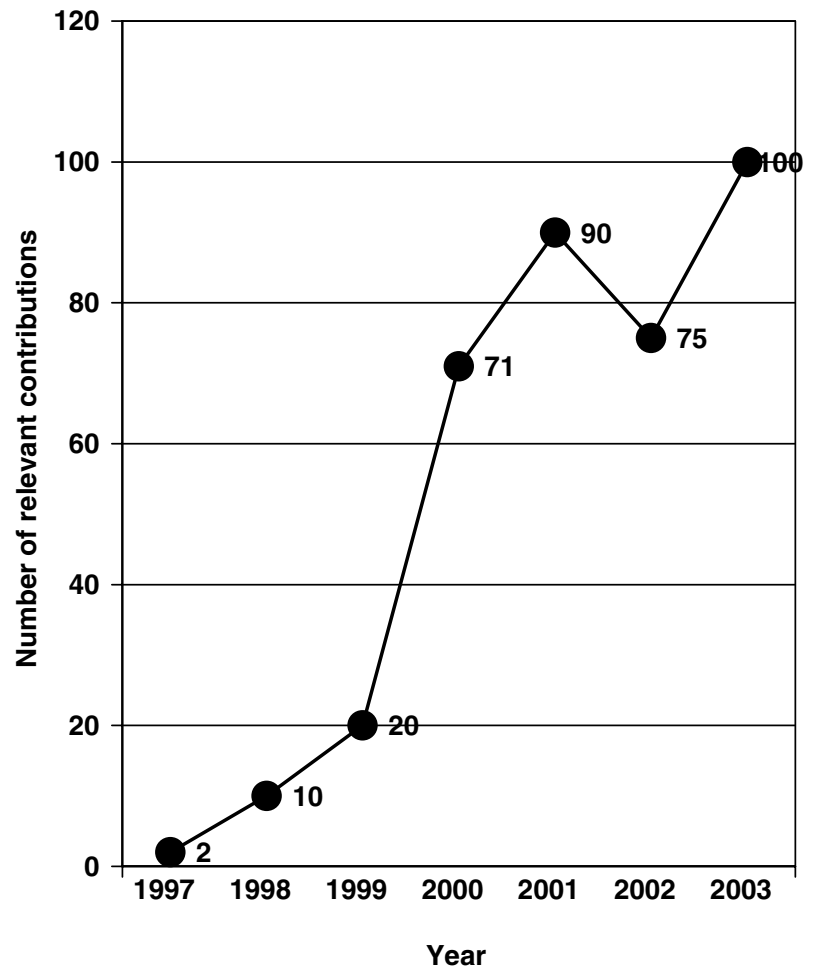

Figure 1. Number of contributions related to evidence-based dentistry (total, 368) published in 28 German-language dental journals 1997-2003.

The highest proportion of relevant papers was published in the quarterly periodontal journal Parodontologie, followed by Dental Magazin (quarterly) and Deutsche Zahnärztliche Zeitschrift (monthly), the latter two both aimed at general dentists. On average, in about six out of 10 issues one could expect to find a contribution related to EBD in these journals. Only one journal, GZM - Praxis und Wissenschaft (Holistic Dentistry - Practice and Science), which is dedicated to complementary and alternative dentistry, was immune to any reference to the concept of EBD.
Ninety-two of the identified articles (25.0\%) referred to EBD in a positive way whereas 268 (72.8\%) were neutral: eight (2.2\%) had a negative perspective. Of the 275 papers published in the 15 journals, which could be searched electronically, only 86 contributions (31.3\%) could be identified in the publisher-owned databases.

\section{Discussion}

Our analysis has shown that EBD has received growing attention in the German-language dental literature, particularly since the year 2000. Nonetheless, considering that 260 issues of dental journals were published in 2003, even a number of 100 contributions is rather modest: the dental community in German-speaking central Europe still appears reluctant to embrace the concept of EBD.

More effort needs to be made, therefore, to advance and popularise this scientifically oriented global concept of health care. The regular series "evidence-based dentistry bits" ("EbM-Splitter"), which has been published bimonthly since February 2001 in Germany's leading scientific dental journal, Deutsche Zahnärztliche Zeitschrift (German Dental Journal), is one example of how dentists may be familiarised with this new approach. Nevertheless, awareness of the existence of EBD is but the first step towards transferring the tools and contents of that concept into local dental practice. At least, however, the finding that only a small minority of authors revealed negative attitudes is promising. The current situation is nicely summarised by JA Muir Gray, "Evidence is global, but its application is local".

1. Clarkson J, Harrison JE, Ismail Al, Needleman I Worthington $\mathrm{H}$ (Eds). Evidence Based Dentistry for Effective Practice, London: Martin Dunitz; 2003.

2. Richards D. 10 years after. Evid Based Dent 2004; 5:87.

3. Türp JC. Evidenzbasierte Zahnmedizin. Inf Orthod Kieferorthop 2004; 36:135-141.

4. Türp JC, Antes G. Evidenzbasierte Zahnmedizin quo vadis? Forum Publ Health 2005; 13 : 25-26.

5. Walther W, Micheelis W (Eds). Evidence-Based Dentistry. Evidenz-basierte Medizin in der Zahn-, Mund- und Kieferheilkunde, Cologne: Deutscher Zahnärzte Verlag DÄV-Hanser; 2000.

6. Muir Gray JA. Foreword. In Evidence Based Dentistry for Effective Practice. Edited by Clarkson J, Harrison JE, Ismail Al, Needleman I, Worthington H. London: Martin Dunitz; 2003; xi-xii. 